\title{
TRANSFUSION REQUIREMENT AND COMPLICATION IN CHILDREN ADMITTED IN A TERTIARY HOSPITAL
}

\author{
V. Booma ${ }^{1}$, K. Palaniappan ${ }^{2}$ \\ ${ }_{1}^{1}$ Associate Professor, Department of Paediatrics, Coimbatore Medical College and Hospital, Coimbatore. \\ ${ }^{2}$ Assistant Professor, Department of Paediatrics, Coimbatore Medical College and Hospital, Coimbatore.
}

\begin{abstract}
BACKGROUND

Indications for transfusion include symptomatic anaemia, haemolytic anaemia, haematological malignancy, acute sickle cell crisis, and acute blood loss of more than 30 percent of blood volume, sepsis, etc. Fresh frozen plasma infusion can be used for reversal of anticoagulant effects. Platelet transfusion is indicated to prevent haemorrhage in patients with thrombocytopenia or platelet function defects. Cryoprecipitate is used in cases of hyperfibrinogenaemia, which most often occurs in the setting of massive haemorrhage or consumptive coagulopathy, factor VIII deficiency and Von Willebrand disease as an alternate to specific component therapy. Transfusion-related infections are less common than non-infectious complications. All non-infectious complications of transfusion are classified as non-infectious serious hazards of transfusion. Acute complications occur within minutes to 24 hours of the transfusion, whereas delayed complications may develop days, months or even years later. Blood transfusion can be a lifesaving procedure, but it has risks, including infectious and non-infectious complications. There is debate in the medical literature concerning the appropriate use of blood and blood products. Clinical trials investigating their use suggest that waiting to transfuse at lower haemoglobin levels is beneficial. This study will consider the indications for transfusion of blood and blood products, and will discuss common non-infectious complications associated with transfusion. Requirement of blood and blood component transfusions in children admitted in a tertiary care hospital and its related complications.
\end{abstract}

\section{OBJECTIVE}

To evaluate the pattern of transfusion requirement in children admitted in a tertiary care hospital and the frequency of transfusion related complications.

\section{METHODS}

Children of various age groups presenting with clinical profile like symptomatic anaemia, haemolytic anaemia, haematological malignancy, acute sickle cell crisis and acute blood loss of more than 30 percent of blood volume, patients with thrombocytopenia or platelet function defects, consumptive coagulopathy, factor VIII deficiency and Von Willebrand disease were taken. All patients who had transfusion related complications like non-infectious serious hazards, infectious complications of blood transfusions, acute transfusion reactions, allergic reactions, transfusion related lung injury, febrile non-haemolytic transfusion reactions, transfusion associated circulatory overload, delayed transfusion reactions will be assessed.

\section{KEYWORDS}

Blood Products, Transfusion Reactions.

HOW TO CITE THIS ARTICLE: Booma V, Palaniappan K. Transfusion requirement and complication in children admitted in a tertiary hospital. J. Evolution Med. Dent. Sci. 2016;5(36):2099-2105, DOI: 10.14260/jemds/2016/493

\section{INTRODUCTION}

Indications for transfusion include symptomatic anaemia, haemolytic anaemia, haematological malignancy, acute sickle cell crisis and acute blood loss of more than 30 percent of blood volume, sepsis, etc. Fresh frozen plasma infusion can be used for reversal of anticoagulant effects. Platelet transfusion is indicated to prevent haemorrhage in patients with thrombocytopenia or platelet function defects. Cryoprecipitate is used in cases of hypofibrinogenaemia, which most often occurs in the setting of massive haemorrhage or consumptive coagulopathy, factor VIII deficiency and Von Willebrand disease as an alternate to specific component therapy.

Financial or Other, Competing Interest: None.

Submission 18-03-2016, Peer Review 14-04-2016,

Acceptance 20-04-2016, Published 04-05-2016.

Corresponding Author:

Dr. V. Booma,

\#46, 50 Feet, Road,

Krishnaswamy Nagar,

Ramanathapuram,

Coimbatore-641045.

E-mail: boomavmohan@yahoo.co.in

DOI: $10.14260 /$ jemds $/ 2016 / 493$
Transfusion-related infections are less common than non-infectious complications. All non-infectious complications of transfusion are classified as non-infectious serious hazards of transfusion. Acute complications occur within minutes to 24 hours of the transfusion, whereas delayed complications may develop days, months or even years later.

Blood transfusion can be a lifesaving procedure, but it has risks including infectious and non-infectious complications. There is debate in the medical literature concerning the appropriate use of blood and blood products. Clinical trials investigating their use suggest that waiting to transfuse at lower haemoglobin levels is beneficial.1,2 The study will consider the indications for transfusion of blood and blood products and will discuss common non-infectious complications associated with transfusion.

\section{AIMS AND OBJECTIVES \\ Primary Objective: To evaluate the pattern of transfusion requirement in children admitted in a tertiary care hospital.}

Secondary Objective: To find out the frequency of transfusion related complications. 


\section{METHODOLOGY}

Study Design: Descriptive study.

Study Place: Department of Paediatrics, Coimbatore Medical College and Hospital (CMCH).

Study Period: June 2014 - May 2015.

Study Population: Includes children admitted in PICU, Department of Paediatrics, and Coimbatore Medical College Hospital, who satisfy the inclusion criteria.

Inclusion Criteria: Children requiring transfusion of blood and blood component.

Exclusion Criteria: Children who died before transfusion.

Sample Size: 1219 Children who required transfusion therapy among the 2837 total admissions in PICU.

Sampling Technique: All children fulfilling inclusion criteria were included.

\section{DEFINITIONS}

PRBC

Packed Red Blood Cells (RBCs) are prepared from whole blood by removing approximately $250 \mathrm{~mL}$ of plasma. One unit of packed RBCs should increase levels of haemoglobin by $1 \mathrm{~g}$ per $\mathrm{dL}(10 \mathrm{~g}$ per $\mathrm{L})$ and haematocrit by 3 percent. ${ }^{3}$

\section{FFP}

FFP is prepared by separating plasma from whole blood and freezed in-22 degrees and stored for max of one year. Thawed plasma that may be stored at 33.8 to $42.8^{\circ} \mathrm{F}\left(1\right.$ to $\left.6^{\circ} \mathrm{C}\right)$ for up to five days. Plasma contains all of the coagulation factors. Fresh frozen plasma infusion can be used for reversal of anticoagulant effects. Thawed plasma has lower levels of factors V and VIII and is not indicated in patients with consumption coagulopathy (Diffuse intravascular coagulation). ${ }^{3}$

\section{Platelets}

One unit of apheresis platelets should increase the platelet count in adults by 30 to $60 \times 10^{3}$ per $\mu \mathrm{L}$ ( 30 to $60 \times 10^{4}$ per L). ${ }^{3}$ One apheresis platelet collection is equivalent to six pooled random donor platelet concentrates. ${ }^{5}$ Here we use random donor platelets concentrate, so it roughly increases platelet concentration by $10,000 / \mathrm{cml}$ of blood in $50 \mathrm{~kg}$ adult.

\section{Cryoprecipitate}

Cryoprecipitate is prepared by thawing fresh frozen plasma and collecting the precipitate. Cryoprecipitate contains high concentrations of factor VIII and fibrinogen. Cryoprecipitate is used in cases of hypofibrinogenaemia, which most often occurs in the setting of massive hemorrhage or consumptive coagulopathy. Indications for cryoprecipitate transfusion are, hypofibrinogenaemia, haemophilia A, VWF, burns, sepsis, etc. Each unit will raise the fibrinogen level by 5 to $10 \mathrm{mg}$ per $\mathrm{dL}$ ( 0.15 to $0.29 \mu \mathrm{mol}$ per $\mathrm{L}$ ), with the goal of maintaining a fibrinogen level of at least $100 \mathrm{mg}$ per dL $(2.94 \mu \mathrm{mol}$ per L).6,7 The usual dose in adults is 10 units of pooled cryoprecipitate.

\section{Manoeuvre}

Children of various age groups presenting with clinical profile like symptomatic anaemia, haemolytic anaemia, haematological malignancy, acute sickle cell crisis and acute blood loss of more than 30 percent of blood volume, patients with thrombocytopenia or platelet function defects, consumptive coagulopathy, factor VIII deficiency and Von Willebrand disease were taken from the total admission to PICU during the study period.

The clinical status, HB level, blood grouping were assessed after obtaining informed consent from the parents. All the cases who required transfusion therapy were given one or more components accordingly. The acute transfusion reactions, like non-infectious serious hazards, infectious complications of blood transfusions, acute transfusion reactions, allergic reactions, transfusion related lung injury, febrile non haemolytic transfusion reactions, transfusion associated circulatory overload. 8,9 delayed transfusion reactions were noted and managed appropriately. They were followed up for 6 months for delayed transfusion reactions like iron overload and infections.

\section{RESULTS}

\section{Male and Female Ratio}

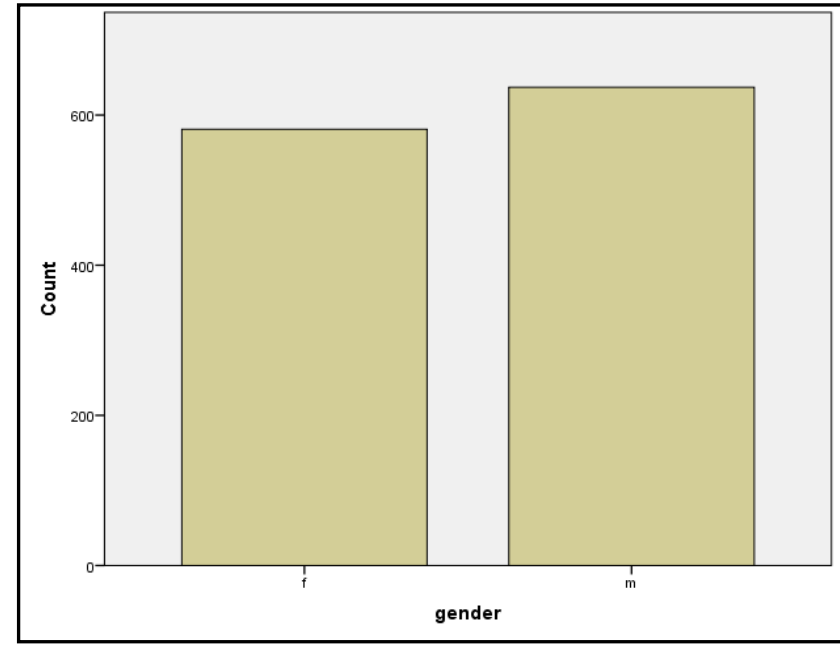

f-female: 582(48\%), m-male: 637(52\%)

The gender distribution showed a little higher incidence in male $(52.22 \%)$ than females $(47.78 \%)$ probably due to haemophilia requiring transfusion therapy is common among males.

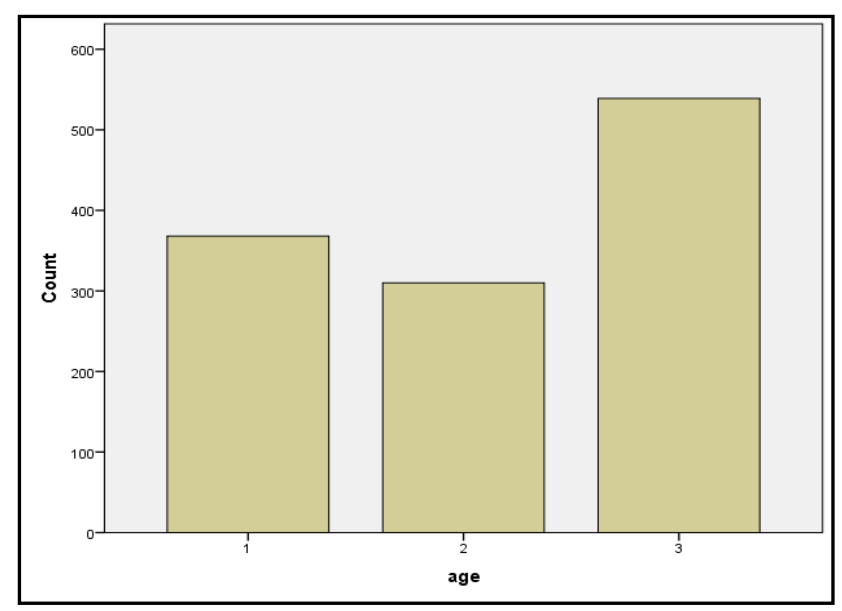

1-Below one year: 368 (31\%), 2-1 to 5 year: 310 (25\%), 3-Above 5 year: 541 (44\%) 
Children less than 1 yr. crossed neonatal period was 368 . The rest 851 subjects were above 1 year of age probably Thalassaemia was the major group requiring transfusion.



O+ve: 456 (37\%), A+ve : 236 (19\%), B+ve :394 (32\%), AB+ve :106 (9\%), O-ve :4 (0.58\%), A-ve :3 (0.42\%), B-ve :20 (2\%)

The most common blood go \%) up required in our study was $0+(37.3 \%)$ followed by $\mathrm{B}+(32.5 \%), \mathrm{A}+(19.3 \%)$, $\mathrm{AB}+(8.6 \%)$. Among the negative blood groups $\mathrm{B}$-ve was $1.6 \%$. Bombay group was not used for transfusion in our study group.

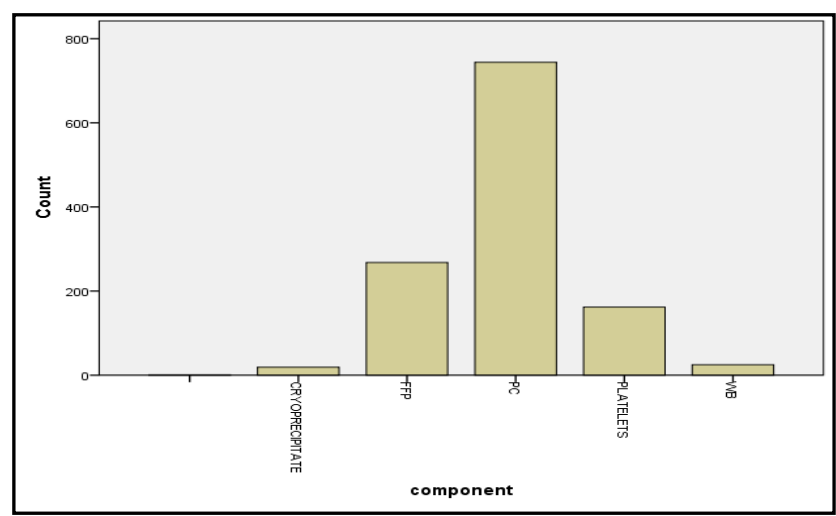

CRYOPRECIPITATE: 20 (2\%), FFP: 268 (22\%), PC: 743 (61\%) PLATELETS: 162 (13\%), WB: 26 (2\%)

\section{INDICATION}

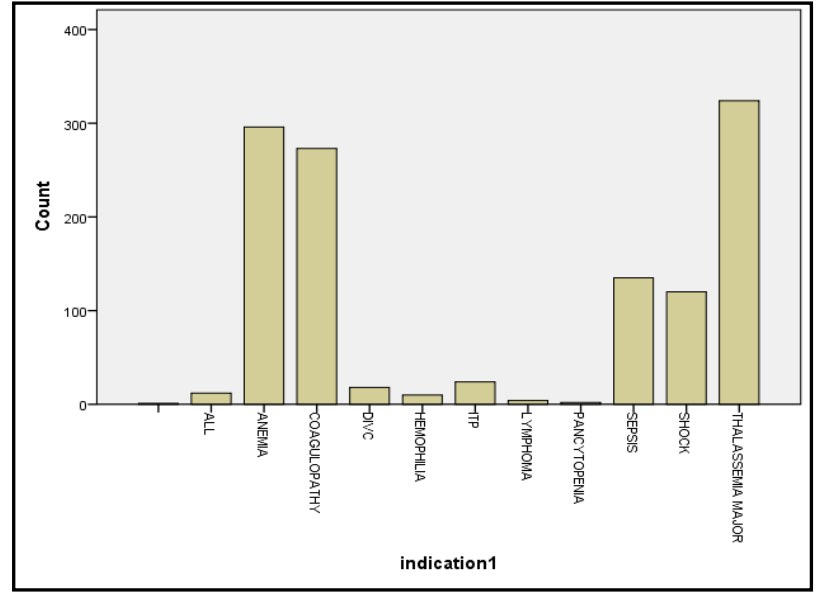

ALL: $1 \%$

ANAEMIA: $24.3 \%$

COAGULOPATHY: $22.4 \%$

DIVC: $1.5 \%$

HEMOPHILA: $0.8 \%$

ITP: $2 \%$

LYMPHOMA: $0.3 \%$

Thalassaemia is a major haematological problem requiring packed cell transfusion followed by shock and anaemia of various aetiologies. Coagulopathies, shock required FFP transfusion, platelet transfusion was indicated in platelet disorders, haemorrhagic fevers and cryoprecipitate was used in the management of haemophilia. Whole blood was again used in shock.

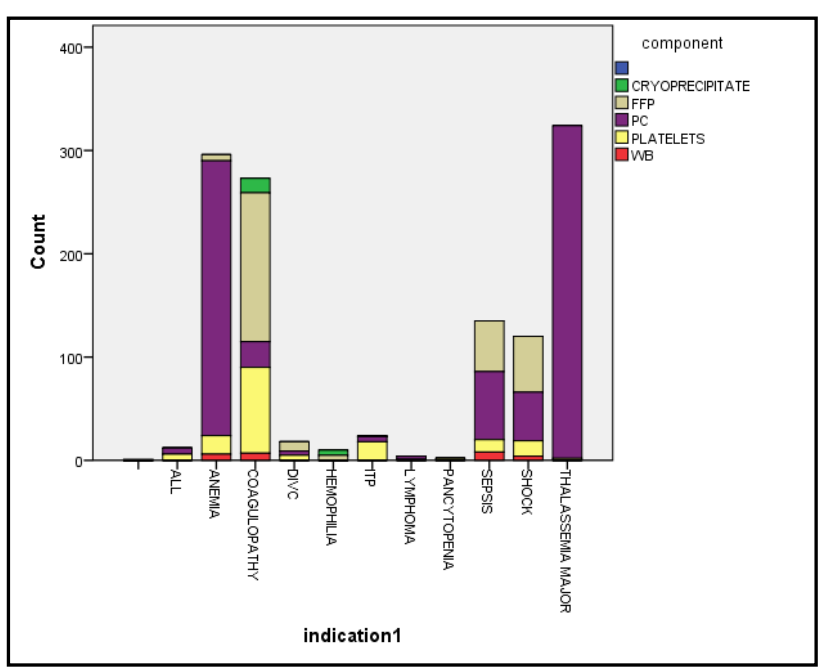

We use PRBC for indications like anaemia, includes nutritional, thalassemia, other haemolytic anaemias, blood loss in haemophilia, ITP, IC bleed, sepsis, DIVC, shock, bone marrow aplasia/suppression in pancytopenias, ALL and lymphomas. Whole blood is rarely used only in shock for volume replacement, florid sepsis. Platelet transfusion here we use single platelets unit from multiple donors. We did not use aparetic units. Common indications are dengue, shock, sepsis, DIVC, large volume PRBC transfusions, ITP, ALL, certain coagulopathies.

FFP used in children for correction of coagulation abnormalities in coagulopathies like haemophilia, VWD, shock, DIVC, sepsis. Very rarely used for volume replacement as we use synthetic colloids for volume replacement. Cryoprecipitate specifically used for haemophilia when factor VIII was not available and in VWD. 
INDICATION 2

Valid

\begin{tabular}{|c|c|c|c|c|}
\hline & Frequency & Percent & Valid Percent & Cumulative Percent \\
\hline & 1 & .1 & .1 & .1 \\
\hline Anaemia & 1 & .1 & .1 & .2 \\
\hline Acute CNS infection & 4 & .3 & .3 & .5 \\
\hline Acute encephalopathy & 4 & .3 & .3 & .8 \\
\hline Acute leukaemia & 4 & .3 & .3 & 1.1 \\
\hline Acute liver failure & 13 & 1.1 & 1.1 & 2.2 \\
\hline ADD with compensated shock & 1 & .1 & .1 & 2.3 \\
\hline ADD with dehydration & 8 & .7 & .7 & 3.0 \\
\hline ADD with failure to thrive & 2 & .2 & .2 & 3.1 \\
\hline ADD with sepsis & 1 & .1 & .1 & 3.2 \\
\hline ADD with shock & 1 & .1 & .1 & 3.3 \\
\hline ADD with some dehydration & 1 & .1 & .1 & 3.4 \\
\hline ADEM & 5 & .4 & .4 & 3.8 \\
\hline AGN & 1 & .1 & .1 & 3.9 \\
\hline ALL & 18 & 1.5 & 1.5 & 5.3 \\
\hline Anaemia & 24 & 2.0 & 2.0 & 7.3 \\
\hline Anaemia & 1 & .1 & .1 & 7.4 \\
\hline Anaemia for evaluation & 9 & .7 & .7 & 8.1 \\
\hline Anaemia with failure & 4 & .3 & .3 & 8.4 \\
\hline $\begin{array}{c}\text { Anaemia with } \\
\text { hepatosplenomegaly }\end{array}$ & 2 & .2 & .2 & 8.6 \\
\hline Anaemia with septicaemia & 2 & .2 & .2 & 8.8 \\
\hline Anaemia with shock & 1 & .1 & .1 & 8.9 \\
\hline Anaemia with splenomegaly & 5 & .4 & .4 & 9.3 \\
\hline Anaemia with thrombocytopenia & 6 & .5 & .5 & 9.8 \\
\hline Aplastic Anaemia & 8 & .7 & .7 & 10.4 \\
\hline ARDS & 4 & .3 & .3 & 10.7 \\
\hline $\mathrm{ARF}$ & 6 & .5 & .5 & 11.2 \\
\hline ARF on PD & 2 & .2 & .2 & 11.4 \\
\hline ARF with anaemia & 2 & .2 & .2 & 11.6 \\
\hline ARF with DIC & 8 & .7 & .7 & 12.2 \\
\hline Aspiration sepsis & 1 & .1 & .1 & 12.3 \\
\hline $\begin{array}{c}\text { Autoimmune haemolytic } \\
\text { anaemia }\end{array}$ & 2 & .2 & .2 & 12.5 \\
\hline Bronchiolitis & 3 & .2 & .2 & 12.7 \\
\hline Bronchopneumonia & 26 & 2.1 & 2.1 & 14.8 \\
\hline CCF with anaemia & 2 & .2 & .2 & 15.0 \\
\hline CCH with cardiogenic shock & 2 & .2 & .2 & 15.2 \\
\hline CHD & 1 & .1 & .1 & 15.3 \\
\hline CHD with CCF with LRI & 2 & .2 & .2 & 15.4 \\
\hline Cholestasis syndrome & 1 & .1 & .1 & 15.5 \\
\hline Cognitive disorder with seizure & 2 & .2 & .2 & 15.7 \\
\hline Compensated shock & 2 & .2 & .2 & 15.8 \\
\hline Congenital heart disease & 1 & .1 & .1 & 15.9 \\
\hline Congenital lobar emphysema & 4 & .3 & .3 & 16.2 \\
\hline congenital neonatal hepatitis & 2 & .2 & .2 & 16.4 \\
\hline $\mathrm{CRF}$ & 1 & .1 & .1 & 16.5 \\
\hline Dengue & 7 & .6 & .6 & 17.1 \\
\hline Dengue fever & 8 & .7 & .7 & 17.7 \\
\hline Dengue haemorrhagic fever & 2 & .2 & .2 & 17.9 \\
\hline Dengue shock syndrome & 3 & .2 & .2 & 18.1 \\
\hline Dengue with compensated shock & 6 & .5 & .5 & 18.6 \\
\hline DIC & 2 & .2 & .2 & 18.8 \\
\hline DIVC & 4 & .3 & .3 & 19.1 \\
\hline DKA & 2 & .2 & .2 & 19.3 \\
\hline DKA with shock & 14 & 1.1 & 1.1 & 20.4 \\
\hline EHPO & 4 & .3 & .3 & 20.8 \\
\hline Encephalopathy & 4 & .3 & .3 & 21.1 \\
\hline Failure to thrive & 8 & .7 & .7 & 21.7 \\
\hline Febrile seizures & 2 & .2 & .2 & 21.9 \\
\hline Fever for evaluation & 2 & .2 & .2 & 22.1 \\
\hline Fever with sepsis & 2 & .2 & .2 & 22.2 \\
\hline Fever with thrombocytopenia & 6 & .5 & .5 & 22.7 \\
\hline GBS & 1 & .1 & .1 & 22.8 \\
\hline
\end{tabular}




\begin{tabular}{|c|c|c|c|c|}
\hline GBS with shock & 2 & .2 & .2 & 23.0 \\
\hline HDN & 6 & .5 & .5 & 23.5 \\
\hline Haematological malignancy & 2 & .2 & .2 & 23.6 \\
\hline Haematemesis & 18 & 1.5 & 1.5 & 25.1 \\
\hline Haemolytic anaemia & 11 & .9 & .9 & 26.0 \\
\hline Haemolytic anaemia with failure & 2 & .2 & .2 & 26.2 \\
\hline Haemolytic anaemia & 2 & .2 & .2 & 26.3 \\
\hline Haemolytic uremic syndrome & 50 & 4.1 & 4.1 & 30.4 \\
\hline Haemophilia A & 25 & 2.1 & 2.1 & 32.5 \\
\hline Hepatic encephalopathy & 6 & .5 & .5 & 33.0 \\
\hline Hodgkin's lymphoma & 2 & .2 & .2 & 33.1 \\
\hline Hydrocephalus & 6 & .5 & .5 & 33.6 \\
\hline Hypertensive encephalopathy & 1 & .1 & .1 & 33.7 \\
\hline IBD & 1 & .1 & .1 & 33.8 \\
\hline ICH & 30 & 2.5 & 2.5 & 36.3 \\
\hline Inborn error of metabolism & 1 & .1 & .1 & 36.3 \\
\hline Infective endocarditis & 6 & .5 & .5 & 36.8 \\
\hline Ipp & 1 & .1 & .1 & 36.9 \\
\hline Iron deficiency anaemia & 1 & .1 & .1 & 37.0 \\
\hline ITP & 18 & 1.5 & 1.5 & 38.5 \\
\hline Langerhans cell histiocytosis & 6 & .5 & .5 & 39.0 \\
\hline Late HDN & 3 & .2 & .2 & 39.2 \\
\hline Late HDN/ICH & 16 & 1.3 & 1.3 & 40.5 \\
\hline Late onset sepsis & 8 & .7 & .7 & 41.2 \\
\hline Leukaemia & 9 & .7 & .7 & 41.9 \\
\hline LHDN & 12 & 1.0 & 1.0 & 42.9 \\
\hline Lymphoma & 4 & .3 & .3 & 43.2 \\
\hline Lymphoma with LRI & 2 & .2 & .2 & 43.4 \\
\hline Lymphoproliferative malignancy & 1 & .1 & .1 & 43.5 \\
\hline Malaria & 2 & .2 & .2 & 43.6 \\
\hline Massive pleural effusion & 2 & .2 & .2 & 43.8 \\
\hline Meningitis & 1 & .1 & .1 & 43.9 \\
\hline Meningitis & 1 & .1 & .1 & 44.0 \\
\hline Myocarditis with shock & 4 & .3 & .3 & 44.3 \\
\hline Near fatal asthma & 5 & .4 & .4 & 44.7 \\
\hline Neonatal cholestasis syndrome & 14 & 1.1 & 1.1 & 45.9 \\
\hline Neurocutaneous syndrome & 1 & .1 & .1 & 45.9 \\
\hline $\begin{array}{l}\text { Neurocutaneous syndrome } \\
\text { c sepsis }\end{array}$ & 1 & .1 & .1 & 46.0 \\
\hline Neurogenic shock & 6 & .5 & .5 & 46.5 \\
\hline Obstructive hydrocephalus & 6 & .5 & .5 & 47.0 \\
\hline Pancytopenia & 8 & .7 & .7 & 47.7 \\
\hline Paraquat poisoning & 3 & .2 & .2 & 47.9 \\
\hline PEM with anaemia & 1 & .1 & .1 & 48.0 \\
\hline PEM with bronchiopneumonia & 2 & .2 & .2 & 48.2 \\
\hline PLHA with severe anaemia & 2 & .2 & .2 & 48.3 \\
\hline Pneumonia & 1 & .1 & .1 & 48.4 \\
\hline Pneumonia with sepsis & 6 & .5 & .5 & 48.9 \\
\hline $\begin{array}{l}\text { Pulmonary Koch disease with } \\
\text { anaemia }\end{array}$ & 2 & .2 & .2 & 49.1 \\
\hline Renal failure & 1 & .1 & .1 & 49.1 \\
\hline Respiratory distress & 1 & .1 & .1 & 49.2 \\
\hline Rta & 2 & .2 & .2 & 49.4 \\
\hline Seizure disorder & 11 & .9 & .9 & 50.3 \\
\hline Sepsis & 23 & 1.9 & 1.9 & 52.2 \\
\hline Septic shock & 21 & 1.7 & 1.7 & 53.9 \\
\hline Septicaemia & 28 & 2.3 & 2.3 & 56.2 \\
\hline Severe acute malnutrition & 2 & .2 & .2 & 56.4 \\
\hline Severe anaemia & 10 & .8 & .8 & 57.2 \\
\hline Severe anaemia & 2 & .2 & .2 & 57.3 \\
\hline Severe anaemia for evaluation & 2 & .2 & .2 & 57.5 \\
\hline Severe anaemia with failure & 2 & .2 & .2 & 57.7 \\
\hline Severe malnutrition & 6 & .5 & .5 & 58.2 \\
\hline Shock & 6 & .5 & .5 & 58.7 \\
\hline Sickle cell anaemia & 17 & 1.4 & 1.4 & 60.0 \\
\hline SLE & 2 & .2 & .2 & 60.2 \\
\hline
\end{tabular}
SLE

2 


\begin{tabular}{|c|c|c|c|c|}
\hline Snake bite & 28 & 2.3 & 2.3 & 62.5 \\
\hline Spastic cerebral palsy & 1 & .1 & .1 & 62.6 \\
\hline $\begin{array}{l}\text { Spastic cerebral palsy C } \\
\text { Pneumonia }\end{array}$ & 1 & .1 & .1 & 62.7 \\
\hline Status epilepticus with shock & 13 & 1.1 & 1.1 & 63.7 \\
\hline TB meningitis & 8 & .7 & .7 & 64.4 \\
\hline Thalassemia major & 322 & 26.4 & 26.4 & 90.8 \\
\hline Thalassemia with shock & 2 & .2 & .2 & 91.0 \\
\hline Thrombocytopenia & 10 & .8 & .8 & 91.8 \\
\hline Vhf & 61 & 5.0 & 5.0 & 96.8 \\
\hline VHF in shock & 1 & .1 & .1 & 96.9 \\
\hline VHF with compensated shock & 1 & .1 & .1 & 97.0 \\
\hline Viral encephalitis & 6 & .5 & .5 & 97.5 \\
\hline Viral encephalitis with shock & 14 & 1.1 & 1.1 & 98.6 \\
\hline Viral exanthematous fever & 2 & .2 & .2 & 98.8 \\
\hline Viral haemorrhagic fever & 2 & .2 & .2 & 98.9 \\
\hline Von-Willebrand's disease & 1 & .1 & .1 & 99.0 \\
\hline Von-Willebrand's disease & 4 & .3 & .3 & 99.3 \\
\hline VSD & 1 & .1 & .1 & 99.4 \\
\hline VSD with failure & 5 & .4 & .4 & 99.8 \\
\hline Wilson's disease & 1 & .1 & .1 & 99.9 \\
\hline With sepsis & 1 & .1 & .1 & 100.0 \\
\hline Total & 1219 & 100.0 & 100.0 & \\
\hline
\end{tabular}

\section{Adverse Reactions}

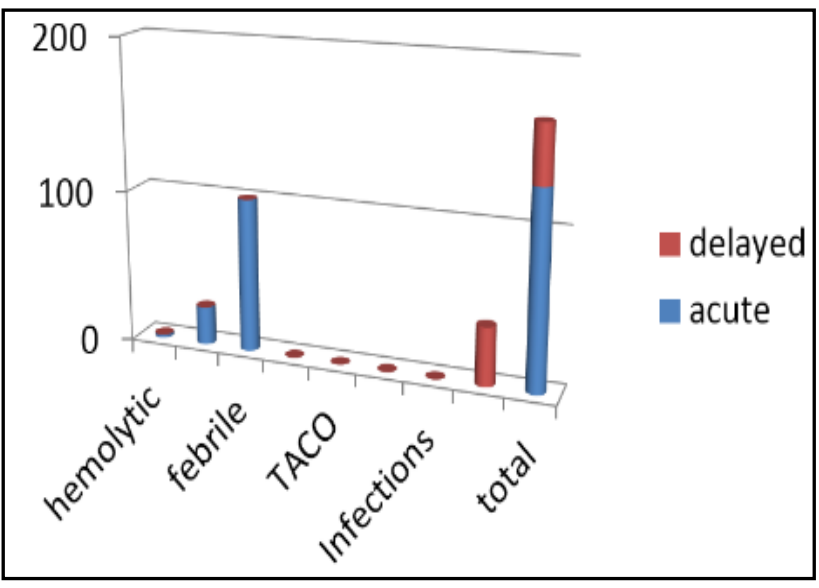

\begin{tabular}{|c|c|c|}
\hline & Acute & Delayed \\
\hline Haemolytic & 2 & 0 \\
\hline Allergic & 25 & 0 \\
\hline Febrile & 100 & 0 \\
\hline TRALI & 0 & 0 \\
\hline TACO & 0 & 0 \\
\hline Ta - & 0 & 0 \\
\hline GVHD & 0 & 0 \\
\hline Infections & 0 & 38 \\
\hline Iron overload & $\mathbf{1 2 7}$ & $\mathbf{3 8}$ \\
\hline Total & &
\end{tabular}

Out of 1219 cases, acute adverse reactions seen in 127 cases and delayed reactions seen in 38 cases. Acute adverse reactions noted in our study are non-allergic febrile reaction (100), allergic (25), haemolytic reaction due to minor incompatibility (2). Iron over load as a delayed and expected complication was seen in 38 transfused thalassemic children. TACO, TRALI, TA- GVHD and infections were not noted in any of the transfused subjects.

\section{DISCUSSION}

The gender distribution did not show any statistically significant difference. Most of the transfusions are in infants below one year: 368 (31\%) mainly attributed to the indications like sepsis, shock, DIVC, etc. Transfusions after infancy is usually for haematological conditions like thalassemias and haemophilias.

Pattern of blood group reflects the distribution of blood group in this part of our country, that if 0 positive, $B$ positive, A positive and $\mathrm{AB}$ positive then negative groups in that order. Majority of the component used is PRBC 743 (61\%) as expected. Mostly the collected blood is processed and separated using component separating machines into FFP, platelets, suspended RBCs before storage. We do not generally keep whole blood at all. We use whole blood for selective indications like exchange transfusion, intraoperative loss, cardio thoracic surgeries, florid sepsis, haemorrhagic shock. This comes only $2 \%$ (26) of the total transfusions. We do get adverse reactions. But life-threatening reactions are rare.

Only 2 cases had haemolytic transfusion reactions and death reported after transfusions is none. Infections also not noted in our study because of very good screening tests protocol and quality control policy. Non allergic febrile and allergic reactions were transient needed supportive therapy and observation only. We did not encounter TRALI, TACO, TAGVHD in our study. Thalassemia is the single most common indication for transfusion therapy. In our study it is $26.6 \%$ and this is due to the high prevalence of thalassemia in our region. All are planned transfusions with fewer reactions. We encounter problem of iron over load and all receive iron chelation as per the recommendation.

\section{CONCLUSION}

- Mostly, we use components than whole blood (98\%, 2\%).

- Commonest component is PRBC.

- Single most common indication is Thalassemia.

- Serious adverse reactions are rare.

- Iron over load is common delayed complication in thalassemic recipients. 


\section{REFERENCES}

1. Hébert PC, Wells G, BLAJCHMAN MA, et al. A multicenter, randomized, controlled clinical trial of transfusion requirements in critical care. Transfusion requirements in critical care investigators, canadian critical care trials group. N Engl J Med 1999;340(6):409-17.

2. Lacroix J, Hébert PC, Hutchison JS, et al. Transfusion strategies for patients in paediatric intensive care units. $\mathrm{N}$ Engl J Med 2007;356(16):1609-19.

3. King KE, Bandarenko N. Blood transfusion therapy: a physician's handbook. Bethesda, Md: American Association of Blood Banks 2008; $9^{\text {th }}$ edn:236.

4. Lichtiger B, Perry-Thornton E. Hemolytic transfusion reactions in oncology patients: experience in a large cancer center. J Clin Oncol 1984;2(5):438-42.
5. Slichter SJ. Platelet transfusion therapy. Haematol Oncol Clin North Am 2007;21(4):697-729.

6. Poterjoy BS, Josephson CD. Platelets, frozen plasma, and cryoprecipitate: what is the clinical evidence for their use in the neonatal intensive care unit? Semin Perinatol 2009;33(1):66-74.

7. Callum JL, Karkouti K, Lin Y. Cryoprecipitate: the current state of knowledge. Transfus Med Rev 2009;23(3):177-88.

8. Hendrickson JE, Hillyer CD. Noninfectious serious hazards of transfusion. Anesth Analg 2009;108(3):759-69.

9. Vamvakas EC, Blajchman MA. Transfusion-related mortality: the ongoing risks of allogeneic blood transfusion and the available strategies for their prevention. Blood 2009;113(15):3406-17. 